\title{
The energy, nutrient and food intakes of teenagers aged 16-17 years in Britain
}

\author{
1. Energy, macronutrients and non-starch polysaccharides \\ BY HELEN F. CRAWLEY \\ School of Life Sciences, The University of North London, Holloway Road, London N7 8DB
}

(Received 17 June 1992-Accepted 18 September 1992)

\begin{abstract}
As part of the 16-17 year follow-up of the 1970 longitudinal birth cohort study, The International Centre for Child Studies collected dietary data from a National sample of $\mathbf{4 7 6 0}$ teenagers. Dietary intake data were collected in $4 \mathrm{~d}$ unweighed dietary diaries, distributed by schools and returned by post. Dietary intake data were quantitatively coded, and the intakes of energy, macronutrients and non-starch polysaccharides (NSP) are reported. Intakes of fat and extrinsic sugars, expressed as a percentage of energy intake, exceeded recent recommendations (Department of Health, 1991), and the intakes of intrinsic sugars, milk sugars and starch, and NSP were considerably lower than recommended. Only $25 \%$ of males and $10 \%$ of females achieved intakes of $18 \mathrm{~g} \mathrm{NSP} / \mathrm{d}$. The main food groups contributing fat ( $\%)$ to the diets of teenagers (for males and females respectively) were meat and meat products $(24 \cdot 2$, $22 \cdot 1)$, spreading fats $(18.6,18 \cdot 1)$ and cereals and cereal products $(18,17.8)$, whilst the major sources of sugars (\%) were (for males and females respectively) sugar and confectionary (28.2, 26.4), cereals and cereal products $(24.5,23)$ and beverages $(21.9,21.5)$. Less than half the cohort drank alcohol during the recording period, and about $6 \%$ of females drank more than 2 units alcohol/d, and about $6 \%$ of males drank more than 3 units alcohol/d.
\end{abstract}

Nutrient intake: Food choice: Teenagers: Dietary survey

A number of large-scale dietary surveys have recently been reported which have examined the nutrient and food intakes of population groups throughout the United Kingdom (Barker et al. 1989; Department of Health, 1989; Gregory et al. 1990). These surveys have demonstrated significant differences between both nutrient and food intakes of teenagers and young adults compared with those of older survey respondents. Despite continuing interest in links between diet and disease, surprisingly little is known about the development of British eating habits, particularly between the teenage years and young adulthood. Longitudinal cohort studies provide a cost effective framework within which dietary habits can be monitored over time, in parallel with changing lifestyles and development of disease.

As part of the 16-17-year data collection sweep of the 1970 longitudinal birth cohort study (Chamberlain et al. 1975), information on dietary habits was collected from a National sample of almost 5000 teenagers. These unique dietary data allow a detailed examination of nutrient and food intakes amongst teenagers throughout Britain and provide a baseline data set from which changes in food choice and nutrient intake can be investigated as the longitudinal study progresses.

The present paper introduces the cohort group and outlines the methodology of the study. It also examines the energy, macronutrient and non-starch polysaccharide (NSP) intakes of this population group and the contributions made by the main food groups to energy and macronutrient intakes. 


\section{Longitudinal birth cohort studies in Britain}

The 1970 longitudinal birth cohort study is the third cohort group established in Britain, following the 1946 National Study of Health and Development (Douglas, 1951) and the 1958 National Child Development Study (Butler \& Bonham, 1963). The 1970 longitudinal birth cohort study was established as a perinatal study, and has followed the health and development of all babies born 5-11 April 1970 (Chamberlain et al. 1975). To date there have been three further data collection sweeps from these cohort members, at 5 years (Osborn et al. 1984), at 10 years (Butler et al. 1982), and in 1986-7 when the cohort were 16 and 17 years of age. This most recent data collection exercise was undertaken by The International Centre for Child Studies, Bristol, between April 1986 and July 1987. The respondents were asked to complete twelve predominantly self-completion documents and two diaries (to collect data on leisure activities and dietary intakes) and were asked to visit their General Practitioner (GP) for a medical examination.

\section{SUBJECTS AND METHODS}

\section{Subjects}

In total, $11710(74 \%)$ of the originally-traced cohort members replied to some aspect of the data collection sweep at 16-17 years. Of the original 15938 cohort members traced in Britain in the original survey week, $13135(82 \%)$ were traced at 5 years and $14906(94 \%)$ cohort members were successfully traced at 10 years of age. The lower response at 16-17 years has been partly attributed to a postal strike, industrial action in schools and impending examinations amongst the cohort group in 1986. Documents were returned between April 1986 and July 1987, and in total 5948 respondents returned a 4 d dietary diary, although a substantial number were blank or incomplete. A total of 4760 completed dietary diaries have been successfully coded and analysed, from 2006 males and 2754 females.

The respondent profile has been examined by sex and region of the country. Sufficient information to classify respondents by social class was available for $1864(92.9 \%)$ males and $2519(91.5 \%)$ females. Although not a truly random nationally and socio-economically representative sample, this cohort provides a valuable survey group since it is large in size and the potential exists for continued longitudinal study.

\section{Measurement of food intake}

Dietary intake data were collected in a $4 \mathrm{~d}$ self-completion dietary diary, with additional information on family food habits and lifestyle factors collected in accompanying questionnaires. The dietary diary was distributed through schools, where appropriate, or by post to the respondent's home. Detailed completion instructions were given both within the diary and sent as an accompanying letter. Respondents were requested to complete the diary on a Friday, Saturday, Sunday and Monday of 1 week, and to include information on the type of food consumed, the brand, the amount eaten, the time of food consumption, and any additional information about their eating habits at that time. The diaries were punctuated with examples, cartoons and reminders to prompt recall and encourage detailed completion.

The dietary diaries were quantitatively coded using relevant information provided in the diaries and standard food portion sizes (Crawley, 1988). Foods were coded from a specially prepared 'food code' list of 1250 foods, which included many items not available in standard food tables at that time, but of particular importance in teenage diets, such as burgers, kebabs, ethnic dishes, vegetarian dishes, lower-fat and higher-fibre products. 
The nutrient database compiled for use in the present study was based on the 4th edition of McCance and Widdowson's The Composition of Foods (Paul \& Southgate, 1978), with additional information on the nutrient content of cooked dishes (Wiles et al. 1980), immigrant foods (Tan et al. 1985), cereal and cereal products (Holland et al. 1988), milk, milk products and eggs (Holland et al. 1989) and vegetables (Holland et al. 1991). Additional information was included from scientific papers (Southgate et al. 1978; Thorn et al. 1978; McLauglin \& Weihrauch, 1979; Greenfield et al. 1981 a, b; Wenlock et al. 1982; Wills \& Greenfield, 1982; Sivell et al. 1984; Englyst et al. 1988). Specific nutrient information which had not been published at that time was obtained from The Ministry of Agriculture, Fisheries and Food (B. Holland, personal communication). Where a food was considered to contain a nutrient, but no reliable information was available, the values were not taken as zero, but a likely value was calculated or estimated from similar foods or recipes. Each 'food code' was assigned to one of eighty discrete food groups so that food choice could be described and examined in some detail.

The coding of dietary diaries was organized and supervised by a dietitian (H.C.) and assistance with coding was provided by trained clerical workers at The International Centre for Child Studies. For the present paper, average energy and nutrient intakes of the cohort were calculated as the mean of the $4 \mathrm{~d}$ intake period, since no significant differences between weekday and weekend nutrient intakes were noted. Since many respondents were revising for exams at home or were on holiday from school during the period of recording, the distinction between weekday and weekend periods may have been less clear.

Data entry was undertaken by a commercial data entry company (DRS Ltd, Milton Keynes), and specially prepared computer programs were written at The University of North London to calculate daily nutrient and food intakes from the appropriate food codes and food weights.

\section{Transcription errors}

Transcription errors are likely to occur whenever data are transcribed manually (Hackett et al. 1983). To assess the number, type and potential effect of such errors, fifty $4 \mathrm{~d}$ records were selected at random, and checked manually. The errors exposed indicated an average of one error appearing every eighty-five lines, with overall coding errors in the 200 person days checked of eight missed food items, twenty-seven incorrect food codes, nine incorrect food weights and three lines punched in duplicate. Calculation of the net change in energy intake per person resulting from these errors suggested a negligible overall change in energy intake of $6.3 \mathrm{~kJ}(1.5 \mathrm{kcals}) /$ person per d. Obviously errors in the food weight or food code of individual items which are relatively dense in a particular nutrient can skew intakes for an individual, and efforts were made to check extreme nutrient intakes to minimize this effect. Despite data cleaning, some extreme values representing errors are likely to remain in such a large data set and for this reason the 2.5 percentile and 97.5 percentile values are used to demonstrate the range of intakes rather than minimum and maximum values. Data interrogation was carried out using SPSS-X version 4.0 (SPSS Inc., 1990) on a VAX computer cluster at The University of North London.

\section{Measurement of height and weight}

Heights and weights of a sub-sample of cohort members who also completed dietary diaries were measured by General Practitioners as part of the present study. Data on measured heights and weights completed at a similar time (within 1 month) to the dietary diary were available for 650 males $(32 \%)$ and 960 females $(35 \%)$, and this sub-sample was representative of the cohort group both regionally and by social class. Estimates of basal metabolic rate (BMR) have been made from standard formulas based on height, weight, 
Table 1. Respondent profile by sex and region for 16-17 year olds studied in Britain*

\begin{tabular}{lccc}
\hline$=$ & Males $(\%)$ & Females $(\%)$ & Population ${ }^{\prime}(\%)$ \\
\hline Region & $7 \cdot 6$ & $8 \cdot 8$ & $8 \cdot 0$ \\
South West & $19 \cdot 1$ & $19 \cdot 6$ & $19 \cdot 0$ \\
South East & $5 \cdot 7$ & $4 \cdot 7$ & $12 \cdot 0$ \\
London & $4 \cdot 7$ & $4 \cdot 2$ & $4 \cdot 0$ \\
East Anglia & $7 \cdot 8$ & $7 \cdot 0$ & $7 \cdot 0$ \\
East Midlands & $10 \cdot 7$ & $10 \cdot 5$ & $9 \cdot 0$ \\
West Midlands & $9 \cdot 2$ & $9 \cdot 4$ & $9 \cdot 0$ \\
Yorkshire and Humberside & $6 \cdot 6$ & $6 \cdot 1$ & $6 \cdot 0$ \\
North & $11 \cdot 2$ & $13 \cdot 0$ & $12 \cdot 0$ \\
North West & $7 \cdot 6$ & $6 \cdot 9$ & $5 \cdot 0$ \\
Wales & $9 \cdot 8$ & $9 \cdot 8$ & $9 \cdot 0$ \\
Scotland & $100 \cdot 0$ & $100 \cdot 0$ & $100 \cdot 0$ \\
Total & & \\
\hline
\end{tabular}

* For details of subjects and procedures, see p. 16.

$\uparrow$ Office of Population Censuses and Surveys (1988).

Table 2. Respondent profile by sex and social class* for 16-17 year olds studied in Britain $\dagger$

\begin{tabular}{llcc}
\hline Social class & Males (\%) & Females (\%) & Populationt (\%) \\
\hline I and Il & 36 & 35 & 35 \\
III non-manual & 13 & 11 & 13 \\
III manual & 36 & 38 & 33 \\
IV and V & 15 & 15 & 18 \\
\hline
\end{tabular}

* Social class data for $91.5 \%$ females and $92.9 \%$ males.

$\div$ For details of subjects and procedures, see p. 16 .

I Office of Population Censuses and Surveys (1988).

age and sex (Schofield et al. 1985). Those used for males and females aged 10-18 years are shown:

$$
\begin{aligned}
\text { male BMR } & =0.068 \text { (weight })+0.574 \text { (height })+2.157 \\
\text { female } B M R & =0.035 \text { (weight })+1.948 \text { (height })+0.837
\end{aligned}
$$

A comparison of energy intake with estimated BMR can be used to estimate the number of respondents in a dietary survey who may be under-reporting their energy intake.

\section{RESULTS}

The respondent profile by region and social class is outlined in Tables 1 and 2. Estimates of the BMR:reported energy ratios and the percentage of respondents with BMR:energy values of less than 1.35 and 1.06 respectively are shown in Table 3 . The energy, macronutrient and NSP intakes, and macronutrient intakes expressed as a percentage of energy intake, are shown in Table 4. The intakes of intrinsic sugars and non-milk extrinsic sugars have been calculated from the percentage of individual sugars provided by specific food groups and calculated values for individual sugars in foods. Energy and NSP intakes were higher amongst males than amongst females, and macronutrient intakes in this cohort are compared with those reported in studies of similar age-groups in Table 5. The intakes 
Table 3. Comparison of energy intakes with estimates of basal metabolic rate $(B M R)^{*}$ amongst male and female 16-17 year olds studied in Britain $\dagger \neq$

\begin{tabular}{lccc}
\hline & Males & \multicolumn{2}{c}{ Females } \\
\hline Mean energy intake:BMR for the whole population & 1.56 & 1.48 \\
$\mathrm{SE}$ & & 0.015 & 0.013 \\
Percentage of non-dieting respondents with energy intake: BMR $<1.35$ & 20 & 17 & 6 \\
Percentage of non-dieting respondents with energy intake: $\mathrm{BMR}<1.06$ & 6 & 6
\end{tabular}

* Based on estimates by Schofield et al. (1985).

+ Based on data from 650 males and 960 females.

\$ For details of subjects and procedures, see pp. 16-18.

Table 4. Energy, macronutrient and non-starch polysaccharide intakes and percentage contributions made by macronutrients to energy intakes of 16-17 year olds studied in Britain*

(Mean values with their standard errors)

\begin{tabular}{|c|c|c|c|c|c|c|c|c|}
\hline & \multicolumn{4}{|c|}{ Males } & \multicolumn{4}{|c|}{ Females } \\
\hline & \multirow[b]{2}{*}{ Mean } & \multirow[b]{2}{*}{ SE } & \multicolumn{2}{|c|}{ percentile } & \multirow[b]{2}{*}{ Mean } & \multirow[b]{2}{*}{$\mathrm{SE}$} & \multicolumn{2}{|c|}{ percentile } \\
\hline & & & $2 \cdot 5$ & $97 \cdot 5$ & & & $2 \cdot 5$ & 97.5 \\
\hline \multicolumn{9}{|l|}{ Energy } \\
\hline kcal & 2714 & $14 \cdot 7$ & 1510 & 4160 & 2117 & $10 \cdot 1$ & 1167 & 3203 \\
\hline $\mathrm{MJ}$ & $11 \cdot 4$ & 0.06 & $6 \cdot 3$ & $17 \cdot 3$ & 8.8 & 0.04 & 49 & $13 \cdot 3$ \\
\hline \multicolumn{9}{|l|}{ Fat } \\
\hline $\mathrm{g}$ & $125 \cdot 0$ & $0 \cdot 76$ & $63 \cdot 4$ & $199 \cdot 7$ & $98 \cdot 2$ & 0.53 & $48 \cdot 4$ & $154 \cdot 3$ \\
\hline$\%$ energy (DRV $33 \%$ ) & $41 \cdot 4$ & & $32 \cdot 1$ & $49 \cdot 9$ & $41 \cdot 6$ & & $31 \cdot 7$ & $50 \cdot 4$ \\
\hline \multicolumn{9}{|l|}{ Protein } \\
\hline $\mathrm{g}$ & $83 \cdot 8$ & 0.47 & $46 \cdot 8$ & $129 \cdot 2$ & $65 \cdot 0$ & $0 \cdot 32$ & $34 \cdot 9$ & $101 \cdot 0$ \\
\hline$\%$ energy & $12 \cdot 5$ & & $9 \cdot 1$ & $16 \cdot 9$ & $12 \cdot 5$ & & 8.7 & $17 \cdot 3$ \\
\hline \multicolumn{9}{|l|}{ Non-milk extrinsic sugars } \\
\hline $\mathrm{g}$ & $94 \cdot 8$ & 0.88 & $29 \cdot 5$ & $182 \cdot 3$ & $76 \cdot 6$ & $0 \cdot 61$ & $23 \cdot 2$ & $150 \cdot 1$ \\
\hline$\%$ energy (DRV 10\%) & $13 \cdot 3$ & & $5 \cdot 5$ & $22 \cdot 7$ & $13 \cdot 7$ & & $5 \cdot 9$ & $23 \cdot 2$ \\
\hline \multicolumn{9}{|l|}{$\begin{array}{l}\text { Intrinsic sugars, milk } \\
\text { sugars and starch }\end{array}$} \\
\hline $\mathrm{g}$ & $225 \cdot 1$ & $1 \cdot 31$ & $119 \cdot 7$ & $350 \cdot 5$ & $171 \cdot 5$ & 0.85 & $88 \cdot 0$ & $268 \cdot 3$ \\
\hline$\%$ energy (DRV $37 \%$ ) & $30 \cdot 9$ & & 23.7 & $38 \cdot 6$ & $30 \cdot 2$ & & $22 \cdot 9$ & $38 \cdot 6$ \\
\hline Non-starch polysaccharides & & & & & & & & \\
\hline (g) (DRV $18 \mathrm{~g})$ & $15 \cdot 2$ & & 69 & $27 \cdot 9$ & $12 \cdot 6$ & & $5 \cdot 5$ & $22 \cdot 2$ \\
\hline \multicolumn{9}{|l|}{ Alcohol } \\
\hline $\mathrm{g}$ & $6 \cdot 6$ & $0 \cdot 29$ & 0 & $44 \cdot 9$ & $4 \cdot 6$ & $0 \cdot 18$ & 0 & $29 \cdot 7$ \\
\hline$\%$ energy & 1.7 & & 0 & $11 \cdot 3$ & $1 \cdot 6$ & & 0 & $10 \cdot 1$ \\
\hline
\end{tabular}

DRV, Dietary reference value (Department of Health, 1991).

* For details of subjects and procedures, see pp. 16-17.

of those respondents who achieved less than $33 \%$ of their total energy from fat ( 78 males and 135 females) are shown in Table 6.

The dietary reference value for daily NSP intake of $18 \mathrm{~g}$ or more (Department of Health, 1991) was achieved by $25 \%$ of males and $10 \%$ of females, with $13 \%$ of males and $30 \%$ females achieving intakes of only half that currently recommended.

Alcohol was consumed by $43.9 \%$ of males and $42.5 \%$ of females during the $4 \mathrm{~d}$ period, 
Table 5. Comparison of studies examining the nutrient and food intake of teenagers

\begin{tabular}{|c|c|c|c|c|c|c|c|c|c|}
\hline Reference & $\begin{array}{c}\text { Age } \\
\text { (years) }\end{array}$ & $\begin{array}{l}\text { Sample } \\
\text { size }\end{array}$ & Sex & $\begin{array}{c}\text { Energy } \\
(\mathrm{MJ})\end{array}$ & $\begin{array}{l}\text { Protein } \\
\text { (g) }\end{array}$ & $\begin{array}{l}\text { Fat } \\
(\mathrm{g})\end{array}$ & $\begin{array}{l}\text { Fat }(\% \\
\text { energy) }\end{array}$ & $\begin{array}{l}\text { Carbo- } \\
\text { hydrate } \\
\text { (g) }\end{array}$ & $\begin{array}{c}\text { Total } \\
\text { sugars } \\
\text { (g) }\end{array}$ \\
\hline \multirow[t]{2}{*}{ Hackett et al. (1984) } & $11 \cdot 5-13 \cdot 5$ & 193 & M & $9 \cdot 4$ & $64 \cdot 0$ & $101 \cdot 1$ & $40 \cdot 0$ & 286 & 123 \\
\hline & & 212 & $\mathrm{~F}$ & $8 \cdot 5$ & $55 \cdot 0$ & $92 \cdot 3$ & $40 \cdot 0$ & 256 & 114 \\
\hline \multirow[t]{2}{*}{ Durnin et al. (1974) } & 14 & 198 & M & $10 \cdot 9$ & $78 \cdot 0$ & $115 \cdot 0$ & $39 \cdot 7$ & 334 & -- \\
\hline & & 221 & $\mathrm{~F}$ & $8 \cdot 5$ & $62 \cdot 0$ & $93 \cdot 0$ & $41 \cdot 4$ & 247 & - \\
\hline \multirow[t]{2}{*}{ Department of Health (1989) } & $14-15$ & 513 & M & $10 \cdot 4$ & $74 \cdot 6$ & $106 \cdot 3$ & 37.9 & 324 & 一 \\
\hline & & 461 & $\mathbf{F}$ & $7 \cdot 9$ & $56 \cdot 2$ & $82 \cdot 2$ & $38 \cdot 7$ & 240 & - \\
\hline \multirow[t]{2}{*}{ Cook et al. (1973) } & $15-17$ & 67 & M & $12 \cdot 1$ & $80 \cdot 0$ & - & - & - & - \\
\hline & & 81 & $\mathbf{F}$ & $8 \cdot 6$ & $59 \cdot 0$ & - & - & - & - \\
\hline \multirow[t]{2}{*}{ Bull (1985) } & $15-18$ & 198 & M & $10 \cdot 1$ & $75 \cdot 9$ & 1160 & $42 \cdot 0$ & 270 & 126 \\
\hline & & 184 & $\mathbf{F}$ & $7 \cdot 8$ & $59 \cdot 2$ & $90 \cdot 0$ & $43 \cdot 0$ & 210 & 97 \\
\hline \multirow[t]{2}{*}{ Crawley (present study) } & $16-17$ & 2006 & $\mathbf{M}$ & $11 \cdot 4$ & $83 \cdot \overline{8}$ & $125 \cdot 0$ & $41 \cdot 4$ & 320 & 140 \\
\hline & & 2754 & $\mathbf{F}$ & $8 \cdot 8$ & $65 \cdot 0$ & $98 \cdot 2$ & $41 \cdot 6$ & 248 & 113 \\
\hline \multirow[t]{2}{*}{ Gregory et al. (1990) } & $16-24$ & 214 & M & $10 \cdot 3$ & $81 \cdot 6$ & $103 \cdot 5$ & 37.9 & 282 & 114 \\
\hline & & 189 & $\mathrm{~F}$ & $7 \cdot 1$ & $58 \cdot 5$ & $73 \cdot 6$ & $38 \cdot 7$ & 204 & 92 \\
\hline \multirow[t]{2}{*}{ Barker et al. (1989) } & $16-29$ & 105 & $\mathrm{M}$ & $10 \cdot 7$ & 81.9 & $111 \cdot 4$ & $39 \cdot 2$ & 297 & - \\
\hline & & 110 & $\mathbf{F}$ & $7 \cdot 6$ & $58 \cdot 2$ & $80 \cdot 8$ & $39 \cdot 7$ & 214 & - \\
\hline
\end{tabular}

M, male; F, female.

Table 6. Macronutrient intakes as a percentage of energy for 16-17 year old British respondents* with fat intakes of less than $33 \%$ of total energy

\begin{tabular}{|c|c|c|}
\hline Macronutrient & $\begin{array}{c}\text { Mean intake }(\%) \\
\text { of fat }<33 \% \\
\text { energy } \\
(n 213)\end{array}$ & $\begin{array}{l}\text { Mean intake }(\%) \\
\text { of total sample } \\
(n 4760)\end{array}$ \\
\hline Percentage energy from fat & $30 \cdot 6$ & $41 \cdot 5$ \\
\hline Percentage energy from protein & $12 \cdot 4$ & $12 \cdot 5$ \\
\hline Percentage energy from extrinsic non-milk sugars & $17 \cdot 4$ & $13 \cdot 5$ \\
\hline Percentage energy from intrinsic sugars, milk sugars and starch & $35 \cdot 0$ & $30 \cdot 5$ \\
\hline Percentage energy from alcohol & $4 \cdot 6$ & $1 \cdot 6$ \\
\hline
\end{tabular}

* For details of subjects and procedures, see pp. 16-17.

and alcohol contributed on average less than $2 \%$ of daily energy intakes. The majority of those consuming alcohol had intakes equivalent to, or less than, those currently recommended (Royal College of Physicians, 1987). About $6 \%$ of both sexes reported alcohol intakes equivalent to more than 2 units/d for females and 3 units/d for males.

The contributions made by food groups to the intakes of energy, fat, protein, starch, total sugars and NSP are shown in Tables 7 and 8 . Contributions made by food groups to nutrient intake were not significantly different for males and females, despite large differences in total energy intake.

\section{DISCUSSION}

The methodology of collection of dietary intake data from population groups has been discussed (Marr, 1971; Bull \& Wheeler, 1986; Bingham, 1987), and the choice of method is influenced by the likely response rate, accuracy required and cost (Fehily, 1983). For the 
Table 7. Percentage contribution made by food groups to intake of energy, protein and fat, for 16-17-year-old male and female British respondents*

\begin{tabular}{|c|c|c|c|c|c|c|}
\hline \multirow[b]{3}{*}{ Food group } & \multicolumn{6}{|c|}{ Percentage contribution to daily intake } \\
\hline & \multicolumn{2}{|c|}{ Energy } & \multicolumn{2}{|c|}{ Protein } & \multicolumn{2}{|c|}{ Fat } \\
\hline & Males & Females & Males & Females & Males & Females \\
\hline Milk and milk products & $9 \cdot 2$ & $8 \cdot 8$ & $15 \cdot 7$ & $15 \cdot 3$ & $12 \cdot 6$ & 11.9 \\
\hline Milk & 5.7 & 4.7 & $9 \cdot 3$ & $7 \cdot 9$ & $7 \cdot 0$ & $5 \cdot 5$ \\
\hline Eggs & $2 \cdot 1$ & $2 \cdot 6$ & $4 \cdot 1$ & $4 \cdot 7$ & $3 \cdot 4$ & $4 \cdot 1$ \\
\hline Meat and meat products & $16 \cdot 4$ & $15 \cdot 2$ & $33 \cdot 7$ & $33 \cdot 2$ & $24 \cdot 2$ & $22 \cdot 1$ \\
\hline Pies, burgers, sausages and kebabs & $7 \cdot 1$ & $5 \cdot 8$ & $8 \cdot 8$ & $7 \cdot 2$ & $10 \cdot 2$ & $8 \cdot 3$ \\
\hline Fish and fish products & $1 \cdot 8$ & $1 \cdot 7$ & $5 \cdot 2$ & $5 \cdot 1$ & $2 \cdot 1$ & $2 \cdot 0$ \\
\hline Fats & $7 \cdot 7$ & $7 \cdot 5$ & $0 \cdot 1$ & $0 \cdot 1$ & $18 \cdot 6$ & $18 \cdot 0$ \\
\hline Sugar and confectionery & $7 \cdot 6$ & $7 \cdot 4$ & 1.7 & $1 \cdot 7$ & $4 \cdot 3$ & $4 \cdot 5$ \\
\hline Vegetables & $4 \cdot 1$ & $4 \cdot 6$ & $5 \cdot 6$ & 5.9 & 1.7 & $2 \cdot 4$ \\
\hline Fried potato & $11 \cdot 8$ & $12 \cdot 0$ & $6 \cdot 6$ & $6 \cdot 4$ & $12 \cdot 6$ & $13 \cdot 0$ \\
\hline Fruit and nuts & $2 \cdot 4$ & $3 \cdot 4$ & $1 \cdot 3$ & $1 \cdot 7$ & 1.0 & $1 \cdot 0$ \\
\hline Cereals and cereal products & $29 \cdot 8$ & $28 \cdot 6$ & $24 \cdot 6$ & $23 \cdot 6$ & $18 \cdot 0$ & $17 \cdot 8$ \\
\hline Bread & $10 \cdot 5$ & $9 \cdot 9$ & $12 \cdot 1$ & $11 \cdot 7$ & $2 \cdot 4$ & $2 \cdot 3$ \\
\hline Breakfast cereals & $4 \cdot 0$ & $2 \cdot 9$ & $3 \cdot 3$ & $2 \cdot 4$ & $0 \cdot 7$ & 0.5 \\
\hline Beverages & $6 \cdot 2$ & $6 \cdot 1$ & $1 \cdot 2$ & $0 \cdot 9$ & $0-4$ & 0.4 \\
\hline Miscellaneous & $1 \cdot 5$ & $2 \cdot 1$ & $1 \cdot 1$ & 1.5 & $2 \cdot 1$ & 3.8 \\
\hline
\end{tabular}

* For details of subjects and procedures, see pp. 16-17.

Table 8. Percentage contribution made by food groups to intake of starch, sugars and nonstarch polysaccharides (NSP) for male and female 16-17-year-old British respondents*

\begin{tabular}{|c|c|c|c|c|c|c|}
\hline \multirow[b]{3}{*}{ Food group } & \multicolumn{6}{|c|}{ Percentage contribution to daily intake } \\
\hline & \multicolumn{2}{|c|}{ Starch } & \multicolumn{2}{|c|}{ Sugars } & \multicolumn{2}{|c|}{ NSP } \\
\hline & Males & Females & Males & Females & Males & Females \\
\hline Milk and milk products & 0 & 0 & $10 \cdot 4$ & $9 \cdot 4$ & 0 & 0 \\
\hline Milk & 0 & 0 & $8 \cdot 4$ & $6 \cdot 7$ & 0 & 0 \\
\hline Eggs & $0 \cdot 7$ & $1 \cdot 0$ & $0 \cdot 2$ & $0 \cdot 4$ & 0.4 & 0.6 \\
\hline Meat and meat products & $8 \cdot 1$ & $7 \cdot 3$ & 0.7 & $0 \cdot 8$ & $4 \cdot 8$ & $4 \cdot 3$ \\
\hline Pies, burgers, sausages and kebabs & 6.7 & $5 \cdot 8$ & $0 \cdot 4$ & $0 \cdot 3$ & $3 \cdot 4$ & $2 \cdot 8$ \\
\hline Fish and fish products & 0.9 & 09 & $0 \cdot 1$ & $0 \cdot 1$ & 0.5 & 0.4 \\
\hline Fats & 0 & 0 & 0 & 0 & 0 & 0 \\
\hline Sugar and confectionery & $0 \cdot 7$ & $0 \cdot 8$ & $28 \cdot 2$ & $26 \cdot 4$ & 0.5 & 0.5 \\
\hline Vegetables & $7 \cdot 9$ & $9 \cdot 2$ & $2 \cdot 1$ & $3 \cdot 4$ & $26 \cdot 6$ & $27 \cdot 3$ \\
\hline Fried potato & $22 \cdot 3$ & $23 \cdot 0$ & $1 \cdot 4$ & $1 \cdot 3$ & $18 \cdot 7$ & $17 \cdot 5$ \\
\hline Fruit and nuts & $0 \cdot 2$ & $0 \cdot 3$ & $10 \cdot 0$ & $18 \cdot 4$ & $7 \cdot 4$ & $10 \cdot 6$ \\
\hline Cereals and cereal products & $59 \cdot 0$ & $56 \cdot 4$ & $24 \cdot 5$ & $23 \cdot 0$ & $40 \cdot 8$ & $37 \cdot 9$ \\
\hline Bread & $30 \cdot 5$ & $29 \cdot 9$ & $2 \cdot 4$ & $2 \cdot 2$ & $19 \cdot 0$ & $18 \cdot 7$ \\
\hline Breakfast cereals & $11 \cdot 5$ & 7.9 & $3 \cdot 2$ & $2 \cdot 4$ & $9 \cdot 6$ & $7 \cdot 0$ \\
\hline Beverages & $0 \cdot 2$ & $0 \cdot 3$ & $21 \cdot 9$ & $21 \cdot 5$ & $0 \cdot 1$ & $0 \cdot 1$ \\
\hline Miscellaneous & $0 \cdot 8$ & $1 \cdot 1$ & $1 \cdot 3$ & $1 \cdot 6$ & $0 \cdot 6$ & 0.7 \\
\hline
\end{tabular}

* For details of subjects and procedures, see pp. 16-17. 
determination of food and nutrient intake to examine differences between groups of individuals, a minimum of 3 days recording is recommended (Bingham, 1987). An unweighed 3-4 or $5 \mathrm{~d}$ diary method has been successfully used in other studies (Hackett $e t$ al. 1983; Braddon et al. 1988; Pixley \& Mann, 1988), and this method has the advantage of being economical both in cost and researcher time when large numbers of individuals are to be studied. The unweighed diary method has been suggested as a more accurate representation of eating habits than a $1 \mathrm{~d}$ recall or diet history (Borelli et al. 1989) and less invasive than weighed methods which may lead to conscious or unconscious changes in normal eating pattern (Stockley, 1985; Livingstone et al. 1990).

The disadvantage of this method, particularly when not accompanied by interviewer follow-up, is the translation from diary text of unknown food types or recipes to appropriate food codes and weights. To aid the interpretation of portion size, average food weights collected during a national cohort weighed intake study were used (Crawley, 1988).

The use of standard food portion sizes is suggested as being of particular value when much of the food consumed is purchased pre-packed or from food outlets where standard portion sizes are known (Nettleton \& Nelson, 1980). Since much of the food consumed by this cohort was easily quantifiable (e.g. number of fish fingers, burgers, biscuits, cans of drink) and as an increasingly significant amount of food is consumed outside the home, an unweighed recording method may be particularly appropriate for this age-group.

The validity of dietary surveys has often been questioned, and it has been suggested that energy intakes may be frequently underestimated (Black et al. 1991). The relationship between reported energy intake and estimated BMR has been estimated for respondents in the present study, in an attempt to examine the frequency of under-reporting in terms of both habitual and actual energy intake. The average time use and energy costs of activity amongst 10-18 year olds have been estimated as 1.56 and 1.48 times BMR for males and females respectively (Department of Health, 1991). Mean energy intake:BMR values reported here of 1.57 and 1.48 for males and females compare well with these estimates. Amongst individuals, it is suggested that a BMR:energy intake value less than 1.35 is unlikely to represent habitual intake, and a BMR: energy value of less than 1.06 times BMR is unlikely to represent actual intake over a $4 \mathrm{~d}$ period, in a non-dieting population (Goldberg et al. 1991).

Whilst completing their dietary diary, respondents were asked on an accompanying questionnaire if they had tried to lose weight by dieting. Amongst non-dieting respondents, $17 \%$ of females and $20 \%$ of males had an energy intake: BMR value of less than 1.35 and $6 \%$ of males and females had energy intake:BMR values of less than 1.06 . It can be suggested, therefore, that reported intakes in the present study may represent 'habitual' intakes for a substantial number of respondents. Those respondents with energy: BMR values of less than 1.06 who were not dieting have not been excluded from the data set, since there is also the possibility of a degree of over-reporting in a dietary survey which may make editing at the lower end of the range misleading (Black et al. 1991).

Recent dietary recommendations have suggested that the percentage of energy intakes from fat and from non-milk extrinsic sugars should be reduced, and the intakes of intrinsic sugars, milk sugars and starch, as well as NSP should increase (Department of Health, 1991). In the present study both males and females had similar fat intakes when expressed as a percentage of energy, and this was substantially higher than current recommendations. Energy and macronutrient intakes in the present study are comparable with those found in other studies of similar age-groups in Britain (see Table 5), and provide additional data on the intake of NSP. The comparison of macronutrient intakes, expressed as a percentage of food energy intake, with recent recommendations suggests that few 16-17 year olds achieve these reference values, and this has also been shown in other recent national studies of 
similar age-groups (Bull, 1985; Department of Health, 1989; Gregory et al. 1990). Fat intakes expressed as a percentage of energy in the present study (about $42 \%$ ) were higher than reported previously amongst 14-15 year olds (39\%; Department of Health, 1989), and amongst 16-24 year olds (38\%; Gregory et al. 1990), but similar to those reported amongst $15-18$ year olds (43\%; Bull, 1985). These differences may reflect differences in survey methodology or in the nutrient conversion factors used, but the higher fat intake may be a feature of the diets of this particular age-group. It has been suggested that adolescence is a time of experimentation and rebellion with regard to food habits (Bull, 1985), and if the 'adolescent diet' is continued into adulthood the high intakes of fat are obviously of concern. We can only hypothesize that these older teenagers may adopt the dietary patterns currently observed amongst adults as they themselves enter adulthood. Since a substantial percentage of total fat intake for both males and females in the present study came from the consumption of meat and meat products $(24.2 \%$ for males, $22.1 \%$ for females) and milk and milk products (12.6\% for males, $11.9 \%$ for females), it can be assumed that saturated fat intakes are also likely to be higher than those currently recommended. Examination of the intakes of those respondents who consumed less than $33 \%$ of total energy from fat suggests that this lower percentage of energy from fat was both rarely achieved by teenagers and was also associated with increased intakes of nonmilk extrinsic sugars and alcohol.

The main food groups contributing energy to the diets of teenagers in this cohort were similar to those outlined in other surveys (Department of Health, 1989; Gregory et al. 1990). Contributions to fat intake were similar to those reported elsewhere, with onequarter of fat provided by meat and meat products and one-fifth by cereals and cereal products. Teenagers in the present study had a lower percentage of sugars from milk and milk products compared with adults, and a higher percentage from beverages, sugar, confectionery and fruit. Data collected from a younger teenage cohort (Rugg-Gunn et al. 1986) reported a higher percentage of sugars from sugar and confectionery, and a lower contribution from fruit (particularly amongst girls) and beverages, with similar total sugars intakes. The consumption of sugar and confectionery may decline, therefore, with increasing age, but total sugars intake may be maintained by higher intakes of sweetened beverages and fruit juices. Since dietary sugars are a cause of dental caries, the higher intakes of sweetened beverages by teenagers are of particular concern.

The calculation of NSP intakes amongst population groups in Britain has become possible since the publication of the NSP contents of common foods. Bingham et al. (1990) re-analysed food records from sixty-three males and females and reported mean NSP intakes of $11.6 \mathrm{~g} / \mathrm{d}$, and estimates from the National Food Survey suggest intakes of $12.7 \mathrm{~g} \mathrm{NSP} / \mathrm{d}$ in 1987 (Ministry of Agriculture, Fisheries and Food, 1989). Higher mean intakes of $15.2 \mathrm{~g} / \mathrm{d}$ for males and $12.6 \mathrm{~g} / \mathrm{d}$ for females in the present study may reflect a greater food intake by teenagers than adults, and intakes expressed as g NSP/4.2 MJ (1000 kcal) for respondents in the present study and estimated from Bingham et al. (1990) and the National Food Survey (Ministry of Agriculture, Fisheries and Food, 1989) suggest similar mean intakes of 5-6 g NSP $/ 4 \cdot 2$ MJ. The major sources of NSP in these teenage diets were vegetables, bread, fried potatoes, breakfast cereals and fruit. The large intake of chips and breakfast cereals amongst teenagers (particularly amongst boys) has been noted elsewhere (Department of Health, 1989).

Alcohol intakes amongst the cohort were heavily skewed, with more than half the males and females drinking no alcohol during this period. However, the accuracy of data collected on alcohol intake is questionable, since teenagers may both under-report alcohol intakes if there is parental disapproval, or over-report alcohol intakes to appear more 'adult'. A recent study of teenagers aged 15-17 years in four areas of Britain reported that 
$44 \%$ of teenagers drank alcohol at the age of 17 years (Townsend et al. 1991), which compares well with data recorded in the present study. It has been recommended that the consumption of alcohol is restricted to 14 units/week for women and 21 units/week for men (Royal College of Physicians, 1987). Alcohol intakes expressed as the number of units consumed/d over the $4 \mathrm{~d}$ period, suggest that the majority of teenagers $(94 \%)$ consumed less than 2 or 3 units/d for females and males respectively. A minority reported intakes over the $4 \mathrm{~d}$ period which would exceed the recommended weekly number of standard drinks for adult males and females. If drinking were confined to the weekend, however, then the present method of estimating the contribution of alcohol to energy intake would overstate true intakes, so that the proportion drinking over the recommended limit would be less than $6 \%$.

Longitudinal study of the dietary habits of the present cohort will allow us to examine whether this population group will maintain the dietary habits established up to and including the teenage years, or adopt those generally reported in dietary studies of older adults. Intakes of micronutrients, and the role of personal, demographic and lifestyle variables in the nutrient intake and food choice of this cohort will be discussed in further publications.

The author would like to thank Professor Neville Butler of The International Centre for Child Studies, Bristol, for access to the raw dietary data, Harriet Wood of The University of North London for computer programming, and The Albert Fisher Group for financial assistance.

\section{REFERENCES}

Barker, M. E., McLean, S. I., McKenna, P. G., Reid, N. G., Strain, J. J., Thompson, K. A., Williamson, A. P. \& Wright, M. E. (1989). Diet, Lifestyle and Health in Northern Ireland. Coleraine: Centre for Applied Health Studies, University of Ulster.

Bingham, S. (1987). The dietary assessment of individuals; methods, accuracy, new techniques and recommendations. Nutrition Abstracts and Reviews 57A, 705-742.

Bingham, S. A., Pett, S. \& Day, K. C. (1990). Non-starch polysaccharide intake of a representative sample of British adults. Journal of Human Nutrition and Dietetics 3, 333-337.

Black, A. E., Goldberg, G. R., Jebb, S. A., Livingstone, M. B. E., Cole, T. J. \& Prentice, A. M. (1991). Critical evaluation of energy intake data using fundamental principles of energy physiology. 2. Evaluating the results of published surveys. European Journal of Clinical Nutrition 45, 583-599.

Borelli, R., Cole, T. J., Di Base, G. \& Contaldo, F. (1989). Some statistical considerations on dietary assessment methods. European Journal of Clinical Nutrition 43, 453-463.

Braddon, F. E. M., Wadsworth, M. E. J., Davies, J. M. C. \& Cripps, H. A. (1988). Social and regional differences in food and alcohol consumption and their measurement in a national birth cohort. Journal of Epidemiology and Community Health 42, 341-349.

Bull, N. (1985). Dietary habits of 15-25 year olds. Human Nutrition: Applied Nutrition 39A, Suppl. 1, pp. 1-68.

Bull, N. L. \& Wheeler, E. F. (1986). A study of different dietary survey methods among 30 civil servants. Human Nutrition: Applied Nutrition 40A, 60-66.

Butler, N. R. \& Bonham, D. G. (1963). Perinatal mortality. First report of the 1958 perinatal mortality survey. Edinburgh: E \& S Livingstone.

Butler, N. R., Haslum, M. N., Barker, W. \& Morris, A. C. (1982). Child Health and Education Study. First Report to the Department on Education and Science on the 10 Year Follow-up. Bristol: University Bristol.

Chamberlain, R., Chamberlain, G., Howlett, B. \& Claireaux, A. (1975). British Births 1970. vol. 1, pp. 1-8. The First Week of Life. London: William Heinemann Medical Books Ltd.

Cook, J., Altman, D. G., Moore, D. M. C., Topp, S. G., Holland, W. W. \& Elliott, A. (1973). A survey of the nutritional status of schoolchildren. British Journal of Preventative and Social Medicine 27, 91-99.

Crawley, H. (1988). Food Portion Sizes. London: H.M. Stationery Office.

Department of Health (1989). The Diets of British Schoolchildren. Report on Health and Social Subjects no. 36. London: H.M. Stationery Office.

Department of Health (1991). Dietary Reference Values for Food Energy and Nutrients for the United Kingdom. Report on Health and Social Subjects no. 41. London: H.M. Stationery Office.

Douglas, J. W. B. (1951). The health and survival of children in different social classes: The results of a national survey. Lancet ii, $440-446$. 
Durnin, J. V. G. A., Lonergan, M. E., Good, J. \& Ewan, A. (1974). A cross-sectional nutritional and anthropometric study, with an interval of 7 years, on 611 young adolescent schoolchildren. British Journal of Nutrition 32, 169-179.

Englyst, H. N., Bingham, S. A., Runswick, S. A., Collinson, E. \& Cummings, J. A. (1988). Dietary fibre (nonstarch polysaccharides) in fruit, vegetables and nuts. Journal of Human Nutrition and Dietetics 1, 247-286.

Fehily, A. M. (1983). Epidemiology for Nutritionists 4. Survey methods. Human Nutrition: Applied Nutrition 37A, 419-425.

Goldberg, G. R., Black, A. E., Jebb, S. E., Cole, T. J., Murgatroyd, P. R., Coward, W. A. \& Prentice, A. M. (1991). Critical evaluation of energy intake data using fundamental principles of energy physiology. 1. Derivation of cut-off limits to identify under-recording. European Journal of Clinical Nutrition 45, 569-581.

Greenfield, H., Chuah, L. K. \& Wills, R. B. H. (1981 a). Composition of Australian foods. 12. Hamburgers. Food Technology Australia 33, 619-620.

Greenfield, H., Wimalasiri, P., Han, L. T. N., Balmer, N. \& Wills, R. B. H. (1981b). Composition of Australian foods. 6. Chinese foods. Food Technology Australia 33, 176-181.

Gregory, J., Foster, K., Tyler, H. \& Wiseman, M. (1990). The Dietary and Nutritional Survey of British Adults. London: H.M. Stationery Office.

Hackett, A. F., Rugg-Gunn, A. J. \& Appleton, D. R. (1983). Use of a dietary diary and interview to estimate the food intake of children. Human Nutrition: Applied Nutrition 37A, 293-300.

Hackett, A. F., Rugg-Gunn, A. J., Appleton, D. R., Eastoe, J. E. \& Jenkins, G. N. (1984). A two-year longitudinal nutritional survey of 405 Northumberland children initially aged 11.5 years. British Journal of Nutrition 51, 67-74.

Holland, B., Unwin, I. \& Buss, D. H. (1988). Cereals and Cereal Products. Third Supplement to McCance and Widdowson's The Composition of Foods. London: H.M. Stationery Office.

Holland, B., Unwin, I. \& Buss, D. H. (1989). Milk, Milk products and Eggs. Fourth Supplement to McCance and Widdowson's The Composition of Foods. London: H.M. Stationery Office.

Holland, B., Unwin, 1. \& Buss, D. H. (1991). Vegetables and herbs. Fifth Supplement to Mc Cance and Widdowson's The Composition of Foods. London: H.M. Stationery Office.

Livingstone, M. B. E., Davies, P. S. W., Prentice, A. M., Coward, W. A., Black, A. E., Strain, J. J. \& McKenna, P. G. (1990). Comparison of simultaneous measures of energy intake and expenditure in children and adolescents. Proceedings of the Nutrition Society 50,15A.

McLaughlin, P. I. \& Weihrauch, J. L. (1979). Vitamin E content of foods. Journal of the American Dietetic Association 75, 647-665.

Marr, J. W. (1971). Individual dietary surveys: purposes and methods. World Review of Nutrition and Dietetics 13, 105-164.

Ministry of Agriculture, Fisheries and Food (1989). Food Facts no. 10. London: Ministry of Agriculture, Fisheries and Food.

Nettleton, P. A. \& Nelson, M. (1980). Dietary survey methods. 2. A comparison of nutrient intakes within families using household measures and the semi-weighed method of measuring food intake. Journal of Human Nutrition 34, 349-354.

Office of Population Censuses and Surveys (1988). Regional Trends 1986. London: Office of Population Censuses and Surveys

Osborn, A. F., Butler, N. R. \& Morris, A. C. (1984). The Social Life of Britain's Five Year Olds. A report on the Child Health and Education Study. London: Routledge \& Kegan Paul.

Paul, A. A. \& Southgate, D. A. T. (1978). McCance and Widdowson's The Composition of Foods, 4th ed. London: H.M. Stationery Office.

Pixley, F. \& Mann, J. (1988). Dietary factors in the aetiology of gall stones: A case control study. Gut 29, 1511-1515.

Royal College of Physicians (1987). A Great and Growing Evil: The Medical Consequences of Alcohol Abuse. London and New York: Tavistock.

Rugg-Gunn, A. J., Hackett, A. F., Appleton, D. R. \& Moynihan, P. J. (1986). The dietary intake of added and natural sugars in 405 English adolescents. Human Nutrition: Applied Nutrition 40A, 115-124.

Schofield, W. N., Schofield, C. \& James, W. P. T. (1985). Basal metabolic rate. Human Nutrition: Clinical Nutrition 39C, Suppl. 1, 1-96.

Sivell, L. M., Bull, N. L., Buss, D. H., Wiggins, R. A., Scuffam, D. \& Jackson, P. A. (1984). Vitamin A activity in foods of animal origin. Journal of the Science of Food and Agriculture 35, 931-939.

Southgate, D. A. T., Paul, A. A., Dean, A. C. \& Christie, A. A. (1978). Free sugars in foods. Journal of Human Nutrition 32, 335-347.

SPSS Inc. (1990). SPSS-X Users' guide, 4th ed., Chicago: SPSS Inc.

Stockley, L. (1985). Changes in habitual food intake during weighed inventory surveys and duplication diet collections. A short review. Ecology of Food and Nutrition 17, 263-269.

Tan, S. P., Wenlock, R. W. \& Buss, D. H. (1985). Immigrant Foods. Second Supplement to McCance and Widdowson's The Composition of Foods. London: H.M. Stationery Office.

Thorn, J., Robertson, J., Buss, D. H. \& Bunton, N. G. (1978). Trace nutrients. Selenjum in British foods. British Journal of Nutrition 39, 391. 
Townsend, J., Wilkes, H., Haines, A. \& Jarvis, M. (1991). Adolescent smokers seen in general practice: health, lifestyle, physical measurements, and response to anti-smoking advice. British Medical Journal 303, 947-950, Wenlock, R. W., Buss, D. H., Moxon, R. E. \& Bunton, N. G. (1982). Trace nutrients. 4. Iodine in British foods. British Journal of Nutrition 47, 381 .

Wiles, S. J., Nettleton, P. A., Black, A. E. \& Paul, A. A. (1980). The nutrient composition of some cooked dishes eaten in Britain: a supplementary food composition table. Journal of Human Nutrition 34, 189-223.

Wills, R. B. H. \& Greenfield, H. (1982). Composition of Australian foods. 17. Snack foods. Food Technology Australia 34, 452-455. 